\title{
Microbiological transformations 57. Facile and efficient resin-based in situ SFPR preparative scale synthesis of an enantiopure "unexpected" lactone regioisomer via a Baeyer-Villiger oxidation process
}

\author{
Iris Hilker, ${ }^{[a]}$ María C. Gutiérrez, ${ }^{[a]}$ Véronique Alphand, ${ }^{[a]}$ Roland Wohlgemuth ${ }^{[b]}$ and \\ Roland Furstoss $^{[\mathrm{a}] *}$ \\ ${ }^{[a]}$ Groupe Biocatalyse et Chimie Fine, UMR CNRS 6111, Université de la Méditerranée, Faculté \\ des Sciences de Luminy, Case 901, 163 avenue de Luminy, 13288 Marseille Cedex 9, France \\ furstoss@luminy.univ-mrs.fr \\ ${ }^{[b]}$ Department of Biochemistry, Fluka AG, PO Box 260, 9470 Buchs, Switzerland
}

\section{EXPERIMENTAL SECTION}

\section{I - Materials}

${ }^{1} \mathrm{H}$ and ${ }^{13} \mathrm{C}$ NMR spectra were recorded on a Bruker AC 250 spectrometer in $\mathrm{CDCl}_{3}$ solutions. Chemical shifts $(\delta)$ are quoted in ppm with $\mathrm{Me}_{4} \mathrm{Si}$ as reference. Gas chromatography analyses were performed on a Shimadzu GC-14A chromatograph equipped with a FID using helium as carrier gas (1.2 bars). Capillary columns were an Optima 5 (25m×0.25mm - Macherey-Nagel) and a Chirasil-Dex $(25 \mathrm{~m} \times 0.25 \mathrm{~mm}$ Chrompak $)$.

\section{II - Chemicals}

The media components for fermentation [soybean peptone (70178), yeast extract (70161), glycerol, ampicilline sodium salt, L-(+)-arabinose (99\%)] as well as (-) bicyclo(3.3.0)hept-2-en6-one $1(\mathrm{ee}=94 \%)$ and Optipore L-493 resin (Dow) were obtained from Fluka.

\section{III - Analytics}

Determination of glycerol concentration. Glycerol concentration in the culture medium was checked using an enzymatic UV assay (Scil Enzytec ${ }^{\mathrm{TM}}$ Glycerol ID-No. 1002 809).

Substrate and product concentration. Concentrations of bicyclo[3.2.0]hept-2-en-6-one 1 and its corresponding lactones $\mathbf{2}$ and $\mathbf{3}$ were determined by extraction of a sample of the aqueous phase with ethyl acetate containing $0.5 \mathrm{~g} / \mathrm{L}$ undecane as internal standard. Samples of adsorbent material were extracted with ethyl acetate only. The organic phase was then analyzed at $110{ }^{\circ} \mathrm{C}$ 
with Optima-5 column. Enantiomeric excess of the lactones was determined on a chiral ChirasilDex column at $110^{\circ} \mathrm{C}$.

\section{IV - Fermentation of E. coli TOP10(pQR239)}

The growth medium was composed of $10 \mathrm{~g} / \mathrm{L}$ glycerol, $10 \mathrm{~g} / \mathrm{L}$ yeast extract, $10 \mathrm{~g} / \mathrm{L}$ soybean peptone and $10 \mathrm{~g} / \mathrm{L} \mathrm{NaCl}$. It was autoclaved at $115{ }^{\circ} \mathrm{C}$ for $20 \mathrm{~min}$. Immediately before inoculation, $1 \mathrm{~g} / \mathrm{L}$ ampicilline, sterilized by filtration, was added as an aqueous solution.

The first preculture has a volume of $10 \mathrm{~mL}$ (in a $100 \mathrm{~mL}$ shake flask) and was inoculated with $300 \mu \mathrm{L}$ of stock culture of E. coli TOP10 (pQR239) kept at $-80^{\circ} \mathrm{C}$. After $6 \mathrm{~h}$ growth at $37^{\circ} \mathrm{C}$, $300 \mu \mathrm{L}$ cells were inoculated into the second preculture of $6 \times 75 \mathrm{~mL}$ in $500 \mathrm{~mL}$ shake flasks. These were grown over night at $37{ }^{\circ} \mathrm{C}$ and inoculated into $5 \mathrm{~L}$ of growth medium in a stirred $10 \mathrm{~L}$ fermenter (Bioflo 3000, New Brunswick Scientific, N.Y., USA) equipped with pH and oxygen probes. Growth conditions in the fermenter were $\mathrm{pH} 7.2$ adjusted with $1 \mathrm{M} \mathrm{KOH}$ and $1 \mathrm{M} \mathrm{H}_{3} \mathrm{PO}_{4}$, agitation speed of $500 \mathrm{rpm}$ and an aeration of $1.3 \mathrm{vvm}$. The cells grew up within 5-6 h and their induction took place in the late log phase by adding L-(+)-arabinose in a concentration of $1 \mathrm{~g} / \mathrm{L}$ to the fermenter. One hour after induction, cells were harvested $\left(\mathrm{OD}_{590}=12\right)$ in their medium and stored at $4{ }^{\circ} \mathrm{C}$ for further use (3-5 days without significant loss of activity if glycerol was not depleted). The BVase activity $^{7}$ (against $\mathbf{1}$ ) was about $95 \mathrm{U} / \mathrm{g}$ dry cells.

\section{V - Biotransformation procedure}

Loading of the substrate onto the adsorbent. The adsorbent was loaded with ketone 1 separately before biotransformation. Dowex Optipore L-493 was used as received with a current degree of humidity of 48\%. $25 \mathrm{~g}$ (0.23 moles) of (-)-bicyclo[3.2.0]hept-2-en-6-one 1, $145 \mathrm{~g}$ of humid Optipore L-493 and $200 \mathrm{~mL}$ of culture medium were shaken gently during one hour to equilibrate.

Biotransformation. 1.2 L of cell broth (stored at $4{ }^{\circ} \mathrm{C}$ ) were centrifuged and the pellet was resuspended in the $800 \mathrm{~mL}$ of broth (cell concentration: $8 \mathrm{~g} \mathrm{dcw} / \mathrm{L}$ ) which was then poured into the reactor. The cells were held for half an hour at a temperature of $37^{\circ} \mathrm{C}$ and an aeration of $3.3 \mathrm{vvm}$. The $\mathrm{pH}$ was regulated at 7.2 with $3 \mathrm{M} \mathrm{KOH}$ and $1 \mathrm{M} \mathrm{H}_{3} \mathrm{PO}_{4}$ and a continuous glycerol feeding was installed. Before starting biotransformation, glycerol concentration was adjusted to $10 \mathrm{~g} / \mathrm{L}$ and $2 \mathrm{~mL}$ antifoam (Pluronic PE 1800 - BASF) were added. During biotransformation, glycerol 
concentration was verified regularly and continuous addition was controlled manually. Addition of antifoam was repeated if necessary.

After $10 \mathrm{~h}$, a second cycle of biotransformation was run by simply replace cell broth with fresh biocatalyst from the stock at $4{ }^{\circ} \mathrm{C}$ (cell concentration: $4 \mathrm{~g} \mathrm{dcw} / \mathrm{L}$ ).

\section{$\mathrm{VI}$ - Product isolation and purification}

The culture medium was continuously extracted by $\mathrm{CH}_{2} \mathrm{Cl}_{2}(48 \mathrm{~h})$ and the resin was extracted by ethyl acetate in a Soxhlet extractor. The organic phases was dried over $\mathrm{MgSO}_{4}$ and concentrated by atmospheric pressure distillation. The crude product was simply purified by bulb-to-bulb distillation to give $26 \mathrm{~g}$ of lactone 2 (99\% ee, 93\% chemical purity), obtained as a colorless oil. ${ }^{1} \mathrm{H}$ and ${ }^{13} \mathrm{C}$ NMR spectra were identical to those previously described in literature. ${ }^{3 \mathrm{~b}}$

Purity, ee and absolute configuration of 2:

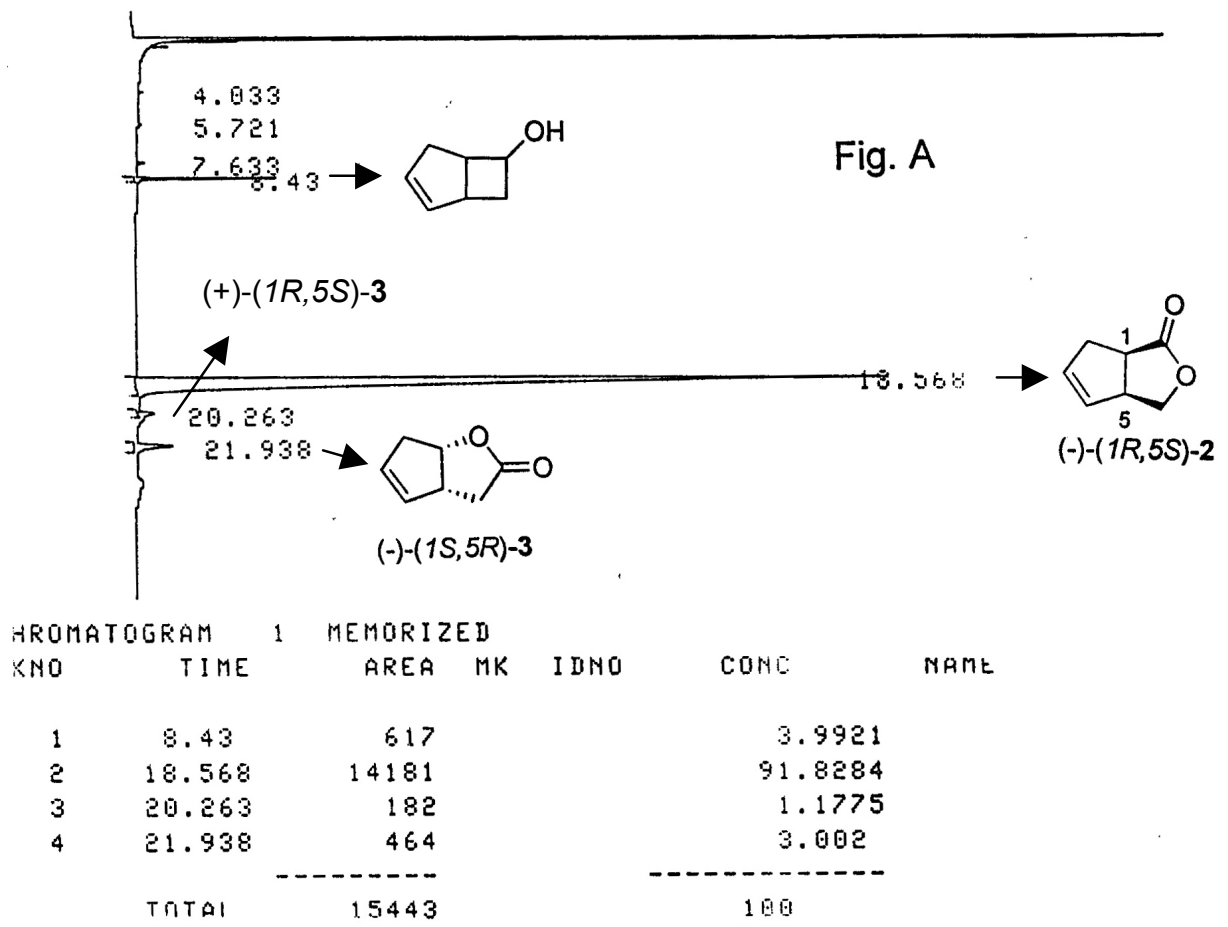

Fig A: GC analysis (Chirasil-Dex column) of (-)-(1R,5S)-2 after bulb-to-bulb distillation. 


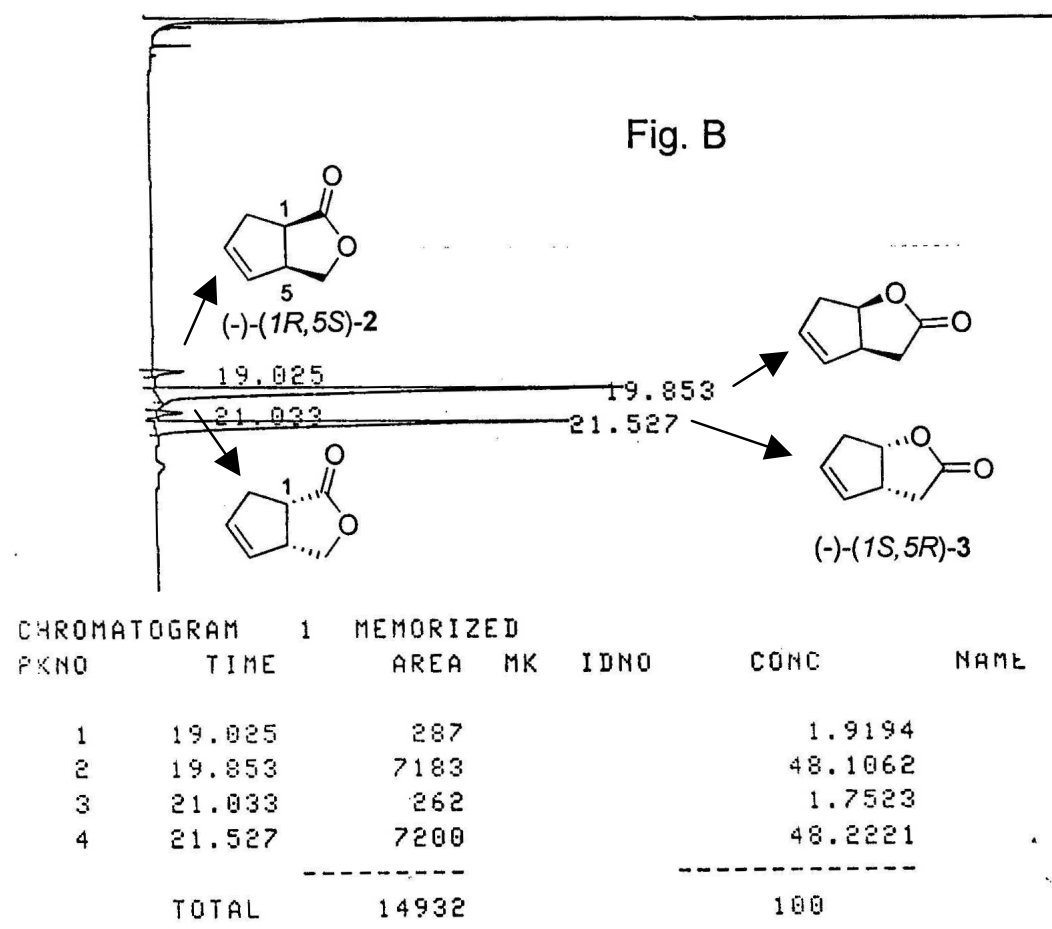

Fig B: GC analysis (Chirasil-Dex column) of a racemic mixture of $\mathbf{2}$ and $\mathbf{3}$ in proportion 4:96 obtained by Baeyer-Villiger oxidation of racemic 1 using peracetic acid.

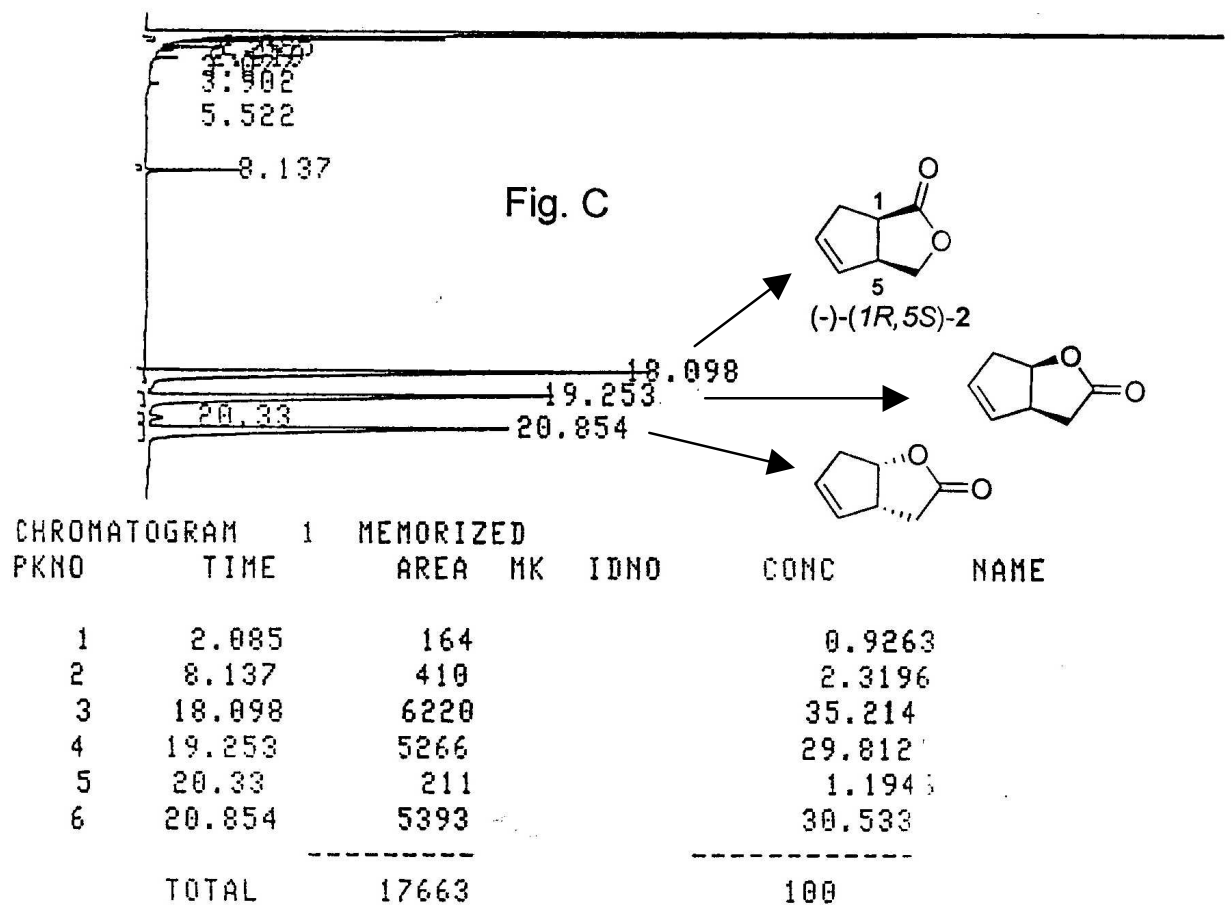

Fig C: GC analysis (Chirasil-Dex column) of a co-injection of above samples ((-)-(1R,5S)-2 and racemic mixture of $\mathbf{2}$ and $\mathbf{3}$ ). 